\title{
Educommunication and Archaeological Heritage in Italy and Spain: An Analysis of Institutions' Use of Twitter, Sustainability, and Citizen Participation
}

\author{
Silvia García-Ceballos ${ }^{1, *} \mathbb{*}$, Pilar Rivero ${ }^{1} \mathbb{D}$, Sebastián Molina-Puche ${ }^{2} \mathbb{D}$ and Iñaki Navarro-Neri ${ }^{1}(\mathbb{D}$ \\ 1 Department of Specific Didactics, Faculty of Education, University of Zaragoza, Calle de Pedro, \\ 50009 Zaragoza, Spain; privero@unizar.es (P.R.); inakinavarro@unizar.es (I.N.-N.) \\ 2 Department of Didactics of Social Sciences Faculty of Education, University of Murcia, 30100 Murcia, Spain; \\ smolina@um.es \\ * Correspondence: sgceballos@unizar.es; Tel.: +34-876-554-865
}

check for updates

Citation: García-Ceballos, S.; Rivero, P.; Molina-Puche, S.; Navarro-Neri, I. Educommunication and

Archaeological Heritage in Italy and Spain: An Analysis of Institutions' Use of Twitter, Sustainability, and Citizen Participation. Sustainability 2021, 13, 1602. https://doi.org/ $10.3390 /$ su13041602

Academic Editor: Eloy

López Meneses

Received: 22 December 2020

Accepted: 1 February 2021

Published: 3 February 2021

Publisher's Note: MDPI stays neutral with regard to jurisdictional claims in published maps and institutional affiliations.

Copyright: (c) 2021 by the authors. Licensee MDPI, Basel, Switzerland. This article is an open access article distributed under the terms and conditions of the Creative Commons Attribution (CC BY) license (https:// creativecommons.org/licenses/by/ $4.0 /)$.

\begin{abstract}
Improving heritage educommunication on the web 2.0 is key to reaching certain sustainable development goals focused on educational quality and citizen participation. Although numerous partial studies have already been conducted, to date neither assessment tools nor detailed studies are available regarding the quality of educommunicative initiatives. Spain and Italy's archaeological heritage museums have a consolidated track record on Twitter, which has been bolstered by museum closures due to COVID-19 and has resulted in a significant change to their educommunicative policies. The present article aims to analyze educommunicative actions undertaken on Twitter at Italian archaeological museums, compare their strategies with a previous study on Spanish institutions, and analyze to what degree the sustainability of heritage, citizen participation, learning opportunities, and universal access are being promoted. This mixed method analysis was carried out through the implementation of a web 2.0 heritage educommunication analysis tool focused on three key factors: educational procedure, R-elational interactions, and the prevailing learning paradigm, as well as a content analysis of the variables that comprise them. The key findings suggest that neither country is close to achieving a quality educommunicative strategy. Italian archaeological heritage institutions use Twitter simply as an advertising platform. Despite being a social media platform, participative initiatives are scarcely promoted, although heritage sustainability is promoted through raising awareness of conservation and appreciation. Spanish institutions, however, demonstrated the opposite pattern of use.
\end{abstract}

Keywords: archaeological museums; COVID-19; twitter; heritage education; educommunication; sustainability; citizen participation

\section{Introduction}

Currently, we live in a context of constant connection, without space or time, where communication utilizes both the rational and the emotional hemispheres of the brain in close and permanent connection. Human beings are connected to a communicative and multisensorial relationship ecosystem without coordinates, which brings together formats, genres, mediums, and content [1]. Due to the present situation, we find ourselves in a highly digital environment, which should be explored from the diverse vantage points of research. This environment allows us to open up new avenues for teaching and bringing society closer [2], in addition to providing a channel for accessible mass communication [3]. This promotes interaction between users and the creation of cyber communities, in the strictest sense of roots and virtual communities [4,5] or digital communities of practice [6]. This has even been described as a space for synergy with a collaborative approach [7] and for co-creation as a key element in sustainability [8]. For these actions to take place, heritage educommunication through social networks is essential [9] as a channel that brings society 
closer to, reveals, and attempts to make heritage understood, as well as to value, enjoy, and, ultimately, educate society about the same. In a context where virtualization makes sense and physical limits are clear, actions to achieve optimum results from proposed objectives must be evaluated.

Educommunication on the web has become fundamental in recent years [10], and the present public health crisis has necessarily bolstered adoption [11]. In the matter at hand, educommunication cannot be isolated since teaching culture, heritage awareness, and, as indicated by United Nations Educational, Scientific and Cultural Organization (UNESCO) [12], the promotion of lifelong learning as a transformative factor that promotes a more participative, multicultural, and sustainable society, requires institutions to establish new educational and communication policies. These must favor knowledge sharing and approximation with society regarding the content they possess and promote, where networks serve as an ally for heritage education in a universal space and context [13].

Over the last decade, the number of studies focused on the use of social networks has increased, while we find ourselves in a changing world in constant evolution that must be studied. Social networks offer an increasing number of ways to consume museums' cultural offering [14] as a means of sociocultural construction and as a tool for media coverage of cultural and historical heritage [15]. There is over a decade of work in this line of research in Spain [16-21], but web 2.0 heritage educommunication is a topic of international interest, as shown by studies from Italy [22-24], Denmark [25,26], Portugal [27], Greece [28], the United Kingdom [29,30], and the United States [31,32]. Likewise, there are world-renowned institutions that have produced various reports [33-36] that represent a starting point for this research.

According to the [33], in 2020 there were about 95,000 museums around the world, 60\% more than in 2012. The distribution of these institutions on the planet is very uneven and this can be seen in the Report on the Implementation of the 2015 UNESCO Recommendation concerning Museums and Collections. This study highlighted the unequal access to the Internet around the world, which has forced the sector to join a global digitization policy focused on aspects such as the digitization of collections, an improvement in inventories, a minimum in infrastructure for scanning and cataloging, Internet access, etc., [34].

This gradual change has been strongly shaken throughout 2020 by the COVID-19 cri-sis, at which time, according to this report, some 85,000 institutions around the world have been forced to close their doors and react quickly in developing its online presence, which, on the other hand, did nothing but highlight the existing digital divide worldwide; only $5 \%$ of museums in Africa and Small Island Developing States (SIDS) have been able to develop content online [33]. These data are corroborated by the report prepared by the International Council Of Museums (ICOM), in which almost 900 responses provided by museums and professionals around the world are collected, in which, despite the improvement in digital activities compared to previous years, the results increased the deep regional differences since the younger museums or those with more fragile structures, especially in Asia, Arab countries, Latin America, and the Caribbean seem to have been the most affected regions [35].

This effort made by museum institutions due to the COVID-19 crisis has followed the line started in 2015 by UNESCO [34], which not only underlined the essential role played by museums in the cultural sphere, but also its importance as an engine of progress and social well-being both in education and in the use of information and communication technologies [33].

Therefore, the relevance of this study (regarding the subject) lies precisely in the fact that emerging fields need a process of construction and settlement based on defined standards and an evaluation that can lead to their improvement. The short history of educommunication in museums does not leave many previous studies, although there are some investigations that address the process of "humanization" or "de-professionalization" in communication from heritage (in the voice of the professionals who guard it, conserve, etc.) towards people [37]. This article is a contribution to the field of knowledge; If 
a new educational scenario is imposed, it is not enough to be there, but a quality action must be carried out so as not to perpetuate a bad practice that lacks significant educational sense or that is not established in line with the Sustainable Development Goals (SDG). This study seeks to know what is being done and to what extent key factors of education, social participation and sustainability are being promoted.

\section{The Present Study}

The present study falls within the scope of a broad Research, Development and Innovation (R\&D\&I) project undertaken by the ARGOS research group focused on web 2.0 heritage education [38]. This focus is based on understanding and analyzing the educommunicative processes and strategies carried out on social media networks by institutions in the non-formal arena of social sciences and heritage education, principally museums [11,39-41]. Specifically, the present study furthers a line of research based on the study of digital archeology heritage educommunication, as it is one of the most representative in the fields of social sciences, and one of the most abundant in digital resources, reconstructions, augmented reality, virtual reality, and virtual tours [42].

As in most fields, digital technology has had a major impact on archeology, and recent studies have taken into account technology management [43], as well as how institutions using this technology communicate and educate through social networks [11]. This latter study constitutes a precedent in its analysis of educommunication carried out on Twitter by Spanish archeology museums during COVID-19 (coronavirus disease); however, Italian museums have always been at the forefront of a systematic review of the literature on this topic $[3,22,24]$. For this reason, this study was expanded to compare these educommunicative strategies.

Apart from its geographic and cultural proximity with Spain, Italy is at the top of UNESCO's list of world heritage sites [44]. Consequently, with such a rich heritage, Italy's communication and education actions are in the spotlight. Some articles have shown relevant findings that merit further study: In an analysis of data from 2011 to 2014, the Virtual Museum Transnational Network (v-must) found that 9 million people in Italy use social networks to inquire about art and culture [3]. As a result, it is worth examining whether museums are responding to the educational factor through social networks. It was important to identify key areas for further action in order to perform a comparative study of the results from both studies. The ultimate goal was to determine whether all of this accumulated experience can establish Italian museums as an example of best practices in educommunication through social networks and highlight possible similarities and differences with other countries that had previously been studied, such as the case of Spain [11].

Apart from this main line of research, the present study analyzed two key factors among the 17 goals for sustainable development promoted by the United Nations. The first deals with educational goal and the 'promotion of lifelong learning opportunities' (SDG4) [45] and the second refers to 'Sustainable cities and communities', specifically, goal 4: 'Strengthen efforts to protect and safeguard the world's cultural and natural heritage' (SDG11) [46]. To achieve both intentions, two factors must be present in the strategies and their content: (1) heritage awareness achieved through the educational focus and objective, and the prevailing type of learning; (2) citizen participation, brought about by the promotion of the R-elational factor $[1,47]$, such that the interaction should happen in a bidirectional manner, encouraging participation, reflection, the processes of co-creation, and feedback. If experiences are significant, the user will establish links, activating the chain of heritage awareness [48] and, thus, the commitment and care necessary to achieve heritage sustainability. The sustainable development goals (SDG) are a priority in the 2030 Agenda $[49,50]$. Likewise, they encourage lifelong learning which, like sustainable development, should be an area of development and ongoing awareness to view learning not just as a simple tool for productivity or consumption, rather as an element of essential personal development [51]. 
Ultimately, this study attempted to answer the following research question by way of a mixed methods investigation: Are the Italian archeology museums present on Twitter participative and educommunicational environments where heritage sustainability and lifelong learning are promoted?

\section{Materials and Methods}

Although there have been prior studies of a similar nature to the one presented here, they have mainly focused on defined aspects of communicative activity for specific events such as museum night [52] or Museum Week [11,22,23], or a generic perspective not centered specifically on educommunicative aspects [53]. In this sense, the main contribution of our study is the detailed analysis of content with an educational purpose to determine what is being done and how it is being done at archeology museums in order to identify weaknesses with the goal of improving educational quality on the web. The following working method was established to achieve this goal: (1) The most widely used hashtags temporarily established by each of the institutions with educational content were selected using a metric analysis tool for Twitter activity [54], which allowed for the numerical recording of activity starting from the date the account was created; (2) The content of the tweets was analyzed through the implementation of a web 2.0 heritage educommunication analytic tool (I-EP2.0) [11]. This tool (see Table 1) uses a comprehensive analysis system focused on three factors: (1) the predominant educational objective from the message, (2) the 'R-elational factor' [1] incorporated to encourage citizen participation, and (3) the prevailing style of learning promoted. Starting from these factors, the educommunicative actions carried out by the institutions studied were assessed, and the degree to which the factors involved in heritage sustainability - citizen participation and heritage awarenesswere promoted was analyzed.

Table 1. Analytical tool for heritage educommunication on the web 2.0.

\begin{tabular}{|c|c|c|}
\hline VARIABLES & INDICATORS & DESCRIPTORS \\
\hline $\begin{array}{l}\text { 1. Purpose of the message } \\
\text { (Heritage Education) }\end{array}$ & $\begin{array}{l}\text { 1.1 Purely transmissive, to make } \\
\text { information known } \\
\text { 1.2 Participatory and interactive proposals } \\
\text { 1.3 Give tools for understanding } \\
\text { 1.4 Promotes values of stewardship, } \\
\text { protection and respect } \\
\text { 1.5 Enjoy and transfer } \\
\text { 1.6 Non-applicable }\end{array}$ & $\begin{array}{l}\text { The main objective is to inform and bring a museum's } \\
\text { collection closer to the public by contextualizing the } \\
\text { works or any other academic data related to a work. } \\
\text { The main objective of the post is to spur the } \\
\text { participation-involvement of Internet users } \\
\text { The post mainly provides content of a reflective nature. } \\
\text { Tries to involve the public so that heritage can come to be } \\
\text { understood as an active part of society. } \\
\text { Involves users to integrate them into the museum's } \\
\text { activities, projects, contests, webquests, etc., enjoying } \\
\text { the process. } \\
\text { It has not any heritage education purpose }\end{array}$ \\
\hline 2. R-elational Factor & $\begin{array}{l}\text { 2.1 Interaction (demonstrative) } \\
\text { 2.2 Reflection (Interpretative) } \\
\text { 2.3 Co-creation (Constructive) } \\
\text { 2.4 Non-applicable }\end{array}$ & $\begin{array}{l}\text { Type of interaction: behavioural, question-answer } \\
\text { (quizzes, trivia, password, etc.). } \\
\text { Through questions, fosters a critical dimension, } \\
\text { helps to interpret. } \\
\text { Transformative, creative, collaborative. } \\
\text { Does not seek participation. }\end{array}$ \\
\hline 3. Dominant learning type & $\begin{array}{l}\text { 3.1 Behaviourism } \\
\text { 3.2 Cognitivism } \\
\text { 3.3 Constructivism } \\
\text { 3.4 Connectivism } \\
\text { 3.5 Non-applicable }\end{array}$ & $\begin{array}{l}\text { There is a question asked by the institution that awaits } \\
\text { the public's answer; there is a question-and-answer } \\
\text { dynamic (password). } \\
\text { The Tweet itself indicates where the answer is } \\
\text { Directly challenges users; appeals to socialization, the } \\
\text { exchange of personal experiences and mixes previous } \\
\text { knowledge with the current context. } \\
\text { It joins the initiative of another institution at the same } \\
\text { time that it connects a current issue with an educational } \\
\text { element of its collection; cites another institution, uses a } \\
\text { specific appearance hashtag (a daily topic, nothing } \\
\text { scheduled or periodic). } \\
\text { It is an advertisement or reply to another account }\end{array}$ \\
\hline
\end{tabular}


The unique circumstances of the COVID-19 pandemic, such as physical museum closures for health reasons, bolstered activity on the web 2.0; as a result, these circumstances set the temporal nature of the analysis.

\subsection{Objectives and Research Questions}

To answer the previously stated research question, the general objective (GO) was to analyze Italian archeology heritage institutions' educommunicative activity on Twitter, with special attention paid to the first semester of 2020 when populations were on lockdown due to the COVID-19 pandemic, and to compare the results obtained with Spanish museums based on the factors incorporated in the SDGs of sustainable heritage, citizen participation and awareness, and lifelong learning.

Likewise, the following specific objectives (SO) were established:

SO1. Quantify Twitter activity generated by Italian archeology and open-air museums during the lockdown due to COVID-19.

SO2. Analyze educommunicative initiatives using hashtags created by museums based on the objective of the message, the R-elational factor, and the prevailing type of learning for the initial months of the health crisis.

SO3. Compare the educommunication carried out on Twitter by Italian archeology museums and sites with that carried out by Spanish archeology and open-air museums.

SO4. Determine whether institutions are promoting sustainable heritage via sustainable development goal number 11.4: 'Strengthen efforts to protect and safeguard the world's cultural and natural heritage' by means of educommunication on Twitter. Overall, two key factors were considered: citizen participation and heritage awareness.

SO5. Analyze to what degree the chosen institutions are committed to Sustainable Development Goal 4: 'promote lifelong learning opportunities for all'.

\subsection{Sample}

The Italian archeology institutions were selected from the official register of 'Ministero per i beni e le attività culturali e per il turismo' (MiBACT) following the search criteria below: "Area Archeologica" ( $=414)$, "Parco Archeologico" ( $=77)$ y "Museo, Galleria e/o racolta" ( $n=372)$; in the latter, only those institutions that included terminology referencing archeology such as 'Archeology Museum' were selected. This yielded a total of $\mathrm{N}=863$ sites or institutions. Subsequently, the sample underwent detailed data filtering, and all instances that did not have an official Twitter account were excluded. In the Italian sphere, this is a complex process because management may be either public or private, and public management is further bifurcated into national and regional. This hinders the identification of accounts, since many are centralized under one official generic regional account $[55,56]$. The sample size was reduced to $n=126$ accounts.

The next selection criterion was the level of activity on the institutions' official Twitter accounts, where a consistent 3-5 tweets per week was considered robust in educommunicative terms. After applying this latest criterion, the final sample size was $n=41$ official Twitter accounts (32.54\% of the 126 accounts identified, only $4.75 \%$ of the 863 locations and institutions listed by the Ministry). Finally, hashtags used in at least 10 tweets were included in the sample for analysis. Since the Italian lockdown lasted for 70 days, writing at least one weekly post with the same hashtag was considered planned activity. In total, 40,641 tweets (26.94\%) from Italian institutions using at least one hashtag were analyzed.

The sample from a study carried out on Spanish archeology and open-air museums [11,40] was used for the comparative analysis. The same procedure for selection was followed. Official data obtained from the Spanish Ministry of Culture and Sport under the heading 'Directory of Museums and Collections' was used, and the search terms 'arqueológico' and 'de sitio' yielded $N=254$ listed institutions. Starting from this figure, the official Twitter accounts for each of these institutions were sought, and a final sample of $n=59$ was obtained, representing just $23.2 \%$ of the total sample. Following the previously described selection criterion (3-5 weekly tweets), a sample of only $n=31$ Spanish institutions showed 
sufficiently consistent activity over the time period examined to indicate planned activity that allowed for the identification of significant examples of educommunicative initiatives. For the Spanish institutions, a higher selection criterion of 40 tweets was used. On the one hand, this was due to a longer social lockdown period in the first semester of 2020 lasting 90 days; on the other hand, the activity between the months of March and June 2020 had to be repeated between three and five times a week. Ultimately, 213,571 tweets, from $n=31$ different Spanish institutions that were active over the last five years, were analyzed. From this activity, 52,408 (24.5\%) were written by the institutions themselves using at least one hashtag which allowed them to be categorized into specific themes.

In summary, $n=72$ official Twitter accounts from Italian $(n=41)$ and Spanish $(n=31)$ institutions in the field of archeology were analyzed in this study. Between tweets with original content, retweets, and shared content there were a total of 364,448 tweets, where only $93,049(25.53 \%)$ were written by the institutions using at least one hashtag (see Figure 1 ).
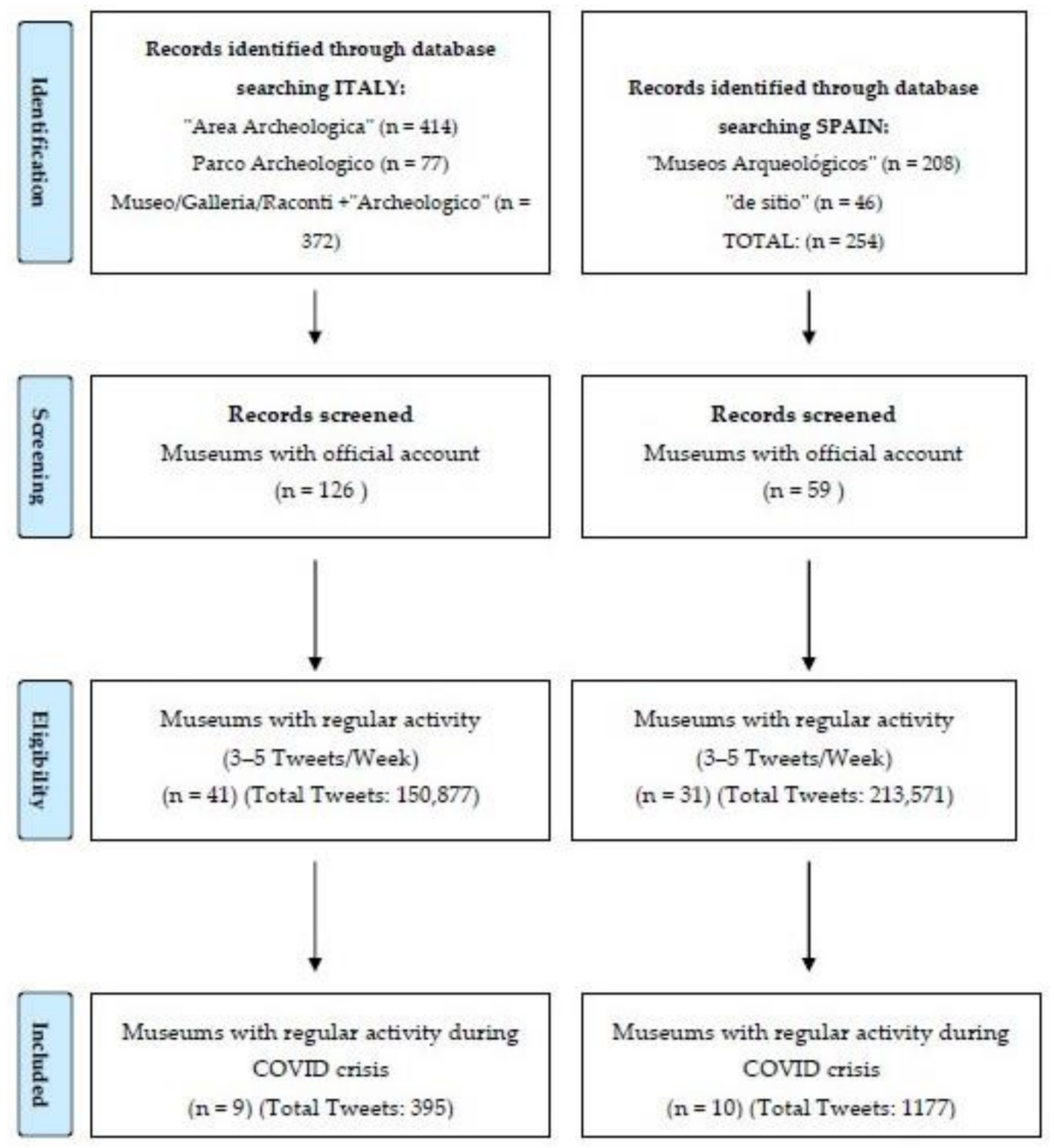

Figure 1. Diagram flow.

\section{Results}

\subsection{Italian Archeology Heritage Institutions in Figures: Twitter Activity}

An initial analysis of the data provided initial quantitative statistics on the institutions: the number of followers, overall activity figures, as well as tweets posted from the total of 3200. This allowed for the creation of an analysis tool for each institution in order to determine the degree of communicative productivity and original activity for each in relation to its most frequently used tweets and hashtags, which were then classified according to the prevailing function (see Table 2). 
Table 2. The Twitter activity of archaeological and Italian open-air museums. The table summarizes the number of followers, activity, and most-used hashtags.

\begin{tabular}{|c|c|c|c|c|c|}
\hline Museum & Followers & Activity Dates & Total Activity & Original Tweets & Most Used Hastag/Function \\
\hline Direzione Regionale Musei dell’Umbria & 1323 & January 2018-September 2020 & 1546 & 1226 & $\begin{array}{l}\text { \#iorestoacasa } \\
157 \text { Tweets/Educational }\end{array}$ \\
\hline Fondazione Brescia Musei & 4337 & July 2016-September 2020 & 8569 & 2838 & $\begin{array}{l}\text { \#Brescia } 137 \\
\text { Tweets/Informative }\end{array}$ \\
\hline MSidicinum & 261 & February 2019-September 2020 & 762 & 108 & $\begin{array}{l}\text { \#iovadoalmuseo } 6 \\
\text { Tweets/Educational }\end{array}$ \\
\hline Musei Calabria & 3289 & December 2015-August 2020 & 974 & 486 & $\begin{array}{l}\text { \#museoeparcoarcheologico } 19 \\
\text { Tweets/Educational }\end{array}$ \\
\hline Musei dell’Umbria & 3807 & May 2018-May 2020 & 9738 & 272 & $\begin{array}{l}\text { \#Umbria } 29 \\
\text { Tweets/Informative }\end{array}$ \\
\hline musei dell'Alto Vicentino & 799 & March 2012-May 2020 & 1773 & 1725 & $\begin{array}{l}\text { \#Valdagno } 2 \\
\text { Tweets/informative }\end{array}$ \\
\hline Musei Molise & 222 & March 2017-July 2020 & 124 & 99 & $\begin{array}{l}\text { \#Molise } 11 \\
\text { Tweets/Informative }\end{array}$ \\
\hline Museo Alife & 360 & March 2019-June 2020 & 775 & 89 & $\begin{array}{l}\text { \#iovadoalmuseo } 8 \\
\text { tweets/Educational }\end{array}$ \\
\hline Museo Archeologico di Calatia & 3434 & April 2018-September 2020 & 6288 & 1113 & $\begin{array}{l}\text { \#MuseumWeek } 38 \\
\text { Tweets/Educational }\end{array}$ \\
\hline $\begin{array}{l}\text { Museo Archeologico di Fregellae } \\
\text { "Amedeo Maiuri" }\end{array}$ & 104 & January 2019-September 2020 & 85 & 60 & $\begin{array}{l}\text { \#Ceprano } 6 \\
\text { Tweets/Informative }\end{array}$ \\
\hline Museo Archeologico Nazionale di Firenze & 8592 & March 2014-June 2020 & 4264 & 2308 & $\begin{array}{l}\text { \#MuseumWeek } 144 \\
\text { Tweets/Educational }\end{array}$ \\
\hline Museo Archeologico Nazionale di Napoli & 8977 & December 2013-August 2020 & 871 & 518 & $\begin{array}{l}\text { \#Napoli } 92 \\
\text { Tweets/Informative }\end{array}$ \\
\hline $\begin{array}{l}\text { Museo Archeologico Nazionale di } \\
\text { Pontecagnano "Gli Etruschi di frontiera" }\end{array}$ & 1129 & June 2017-September 2020 & 1573 & 544 & $\begin{array}{l}\text { \#MAP } 98 \\
\text { Tweets / Informative }\end{array}$ \\
\hline Museo Archeologico Nazionale di Venezia & 12,324 & August 2012-September 2020 & 2973 & 2365 & $\begin{array}{l}\text { \#maggioalmuseo } 49 \\
\text { Tweets/Informative }\end{array}$ \\
\hline Museo Archeologico Nazionale di Verona & 220 & August 2017-September 2020 & 332 & 164 & $\begin{array}{l}\text { \#workinprogress } 12 \\
\text { Tweets/Informative }\end{array}$ \\
\hline Museo Archeologico Sardinia (Cagliari) & 14,001 & March 2018-September 2020 & 31,856 & 1816 & $\begin{array}{l}\text { \#racconti } 111 \\
\text { Tweets/Educative }\end{array}$ \\
\hline Museo Archeologico Virtuale & 4734 & January 2013-August 2020 & 3477 & 2000 & $\begin{array}{l}\text { \#FestivalMemoria } 457 \\
\text { Tweets/Informative }\end{array}$ \\
\hline
\end{tabular}


Table 2. Cont.

\begin{tabular}{|c|c|c|c|c|c|}
\hline Museum & Followers & Activity Dates & Total Activity & Original Tweets & Most Used Hastag/Function \\
\hline Museo del Carbone & 4732 & April 2016-August 2020 & 8078 & 1070 & $\begin{array}{l}\text { \#MuseumWeek } 197 \\
\text { Tweets/Educative }\end{array}$ \\
\hline Museo di Cabras & 1329 & April 2014-May 2020 & 1201 & 1062 & $\begin{array}{l}\text { \#museodicabras } 159 \\
\text { Tweets/Informative }\end{array}$ \\
\hline Museo di Salo & 309 & August 2015-July 2020 & 685 & 581 & $\begin{array}{l}\text { \#Salò } 81 \\
\text { Tweets/Informative }\end{array}$ \\
\hline Museo Eboli & 173 & August 2020-August 2020 & 84 & 12 & $\begin{array}{l}\text { \#gioiellicampani } 1 \\
\text { Tweet/Informative }\end{array}$ \\
\hline Museo Lavinium & 451 & December 2014-September 2020 & 96 & 96 & $\begin{array}{l}\text { \#Pomezia } 20 \\
\text { Tweets/Informative }\end{array}$ \\
\hline Museo Marta. Taranto-Puglia & 4200 & January 2016-September 2020 & 2263 & 1893 & $\begin{array}{l}\text { \#MArTA } 238 \\
\text { Tweets/Informative }\end{array}$ \\
\hline $\begin{array}{l}\text { Museo Regionale di Scienze } \\
\text { Naturali di Torino }\end{array}$ & 2896 & January 2015-September 2020 & 4739 & 2718 & $\begin{array}{l}\text { \#ViaggioDellaMagenta } 132 \\
\text { Tweets/Informative }\end{array}$ \\
\hline Museo Salinas. Palermo & 5668 & July 2015-September 2020 & 4171 & 1009 & $\begin{array}{l}\text { 1\#estoriedituttinoi } 207 \\
\text { Tweets/Informative }\end{array}$ \\
\hline Museosmcv (Antica Capua) & 234 & May 2015-September 2020 & 899 & 892 & $\begin{array}{l}\text { \#viaggioinitalia } 15 \\
\text { Tweets/Educative }\end{array}$ \\
\hline NuragheLosa (Parco Archeologico Losa) & 1569 & February 2013-September 2020 & 784 & 573 & $\begin{array}{l}\text { \#NuragheLosa } 146 \\
\text { Tweets/Informative }\end{array}$ \\
\hline Parchi Valcornia & 1714 & July 2012-June 2020 & 3331 & 1662 & $\begin{array}{l}\text { \#Piombino } 108 \\
\text { Tweets/Informative }\end{array}$ \\
\hline Parco Archeologico dell'Appia Antica & 1195 & June 2018-September 2020 & 554 & 424 & $\begin{array}{l}\text { \#appiaantica } 10 \\
\text { Tweets/Informative }\end{array}$ \\
\hline Parco Archeologico di Ostia Antica & 2271 & August 2016-September 2020 & 1609 & 1234 & $\begin{array}{l}\text { \#vediamociaostiantica } 86 \\
\text { Tweets/Informative }\end{array}$ \\
\hline Parco Archeologico di Paestum e Velia & 4394 & February 2016-September 2020 & 3422 & 1473 & $\begin{array}{l}\text { \#Paestum } 127 \\
\text { Tweets/Informative }\end{array}$ \\
\hline Parco Colosseo & 6678 & November 2018-September 2020 & 4799 & 1506 & $\begin{array}{l}\text { \#igiovedìdelPArCo } 87 \\
\text { Tweets/Educative }\end{array}$ \\
\hline Parco e Museo Genna Maria di Villanovaforru & 552 & December 2012-September 2020 & 145 & 135 & $\begin{array}{l}\text { \#villanovaforru } 10 \\
\text { Tweets }\end{array}$ \\
\hline Parco Incisioni. Grosio & 493 & June 2012-February 2020 & 1045 & 1026 & $\begin{array}{l}\text { \#Valtellina } 17 \\
\text { Tweets/Informative }\end{array}$ \\
\hline
\end{tabular}


Table 2. Cont

\begin{tabular}{|c|c|c|c|c|c|}
\hline Museum & Followers & Activity Dates & Total Activity & Original Tweets & Most Used Hastag/Function \\
\hline Polo Museale Abruzzo & 384 & May 2018-January 2020 & 287 & 269 & $\begin{array}{l}\text { \#Celano } 33 \\
\text { Tweets/Informative }\end{array}$ \\
\hline Polo Museale della Basilicata & 1005 & January 2013-May 2020 & 1474 & 1448 & $\begin{array}{l}\text { \#DomenicalMuseo } 8 \\
\text { Tweets/Informative }\end{array}$ \\
\hline Polo Napoli & 10,487 & April 2016-September 2020 & 4469 & 663 & $\begin{array}{l}\text { \#MuseumWeek } 26 \\
\text { Tweets/Educative }\end{array}$ \\
\hline Pompeii Sites & 29,175 & July 2017-September 2020 & 6223 & 1772 & $\begin{array}{l}\text { \#Pompei } 324 \\
\text { Tweets/Educative }\end{array}$ \\
\hline $\begin{array}{l}\text { Sito UNESCO della Sardegna } \\
\text { (Fondazione Barumini) }\end{array}$ & 653 & November 2013-September 2020 & 264 & 206 & $\begin{array}{l}\text { \#Barumini } 22 \\
\text { Tweets/Informative }\end{array}$ \\
\hline Villa Mosaici Spello & 1351 & February 2018-September 2020 & 3108 & 884 & $\begin{array}{l}\text { \#VillaMosaiciSpello } 190 \\
\text { Tweets/Informative }\end{array}$ \\
\hline
\end{tabular}


As Table 2 shows, there were 41 Italian museums with official Twitter accounts and consistently updated content. The most frequently used hashtags for 28 institutions $(68.29 \%)$ had purely informative or marketing purposes, while for the remaining $13(31.71 \%)$ they had educommunicative purposes. It is worth highlighting that some of the most frequently used educational hashtags emerged during the lockdown such as \#iorestoacasa, used by the Direzione Regionale Musei dell'mbria, \#iovadoalmuseo used by MSidicinum y Museo Alife, or \#Racconti used by the Museo Archeologico Sardegna, Cagliari. This shows there were institutions that chose to use Twitter as an educommunicative environment during the forced closures due to COVID-19.

The same variables from a prior study on Spanish archeology institutions [11], which are key to the comparative analysis in this study, were analyzed. A total of 31 institutions were examined, among which 23 institutions (74.19\%) showed predominantly informational or advertising focused hashtags, whereas the purpose of the most widely used hashtags for only 8 institutions (25.81\%) was educational.

\subsection{Content Analysis of Educommunicative Strategies 2.0}

Spain and Italy faced a very similar series of events and governmental measures taken during the pandemic, due not just to geographic proximity, but also to socioeconomic ties. The respective time periods of government mandated closure of public spaces were used in this study. Although some regions of Lombardy and northern Italy were on lockdown prior to 10 March, the declaration of a nationwide lockdown was used as the start date. The start of progressive reopening on 18 May was used for the end date, for a total of 10 weeks of closure without physical visits to institutions or sites.

Of the 41 official Twitter accounts from Italian institutions in charge of archeology heritage (see Table 2), a consistent educommunicative strategy over the time period examined was found in only 9 cases (21.95\%) (see Table 3 ). Considering the museums analyzed were closed for a total of 70 days, the use of hashtags on, minimally, a weekly basis, such as in the case of Museo Archeologico Nazionale di Venezia, would have been favorable. Their educommunicative policy promoted challenges on Facebook with hashtags like \#Minimamiribilia or \#MonetaSonante. They showed a picture of two items such as gems or coins and a brief explanation of each, then asked internet users to vote for their favorite.

The Direzione Regionale Musei Umbria stands out for frequency and total number of tweets with 157 for the hashtag \#iorestoacasa spanning various educommunicative goals, principally transmission (53.5\%). Secondly, through the combination of three hashtags (\#Archeobuongiorno, \#racconti and \#Laculturanonsiferma) the Museo Archeologico Sardegna carried out a mostly transitive educommunicative policy of a cognitive learning nature where the institution simply provided information about specific items or content.

The first variable (V.1) analyzed the proposed heritage education goal; it is worth noting that $57.47 \%$ of the tweets analyzed were from the lowest stage of the sequence: transmission. Only the Museo Archeologico Nazionale di Venezia produced more participatory posts than purely transmissive ones.

Regarding R-elational initiatives (V.2), the archeology institutions examined scarcely attempted collective dynamics ( $90.89 \%$ of the tweets contained no initiative), and those identified were based on the simplest dynamic (question-response) via questionnaires that Twitter facilitates.

Finally, regarding the proposed learning (V.3), 83.8\% of the initiatives promote a cognitive strategy. That is to say, the institution provided all the information it felt was relevant about a specific piece of its collection. 
Table 3. Analysis and catalogue of educational hashtags used during the lockdown in Italy.

\begin{tabular}{|c|c|c|c|c|c|c|c|c|c|c|c|c|c|c|c|c|c|}
\hline \multirow{2}{*}{ Museum } & \multirow{2}{*}{ Hastags Covid 19} & \multirow{2}{*}{ Tweets } & \multicolumn{6}{|c|}{ V.1 Purpose of the Message } & \multicolumn{4}{|c|}{ V.2 R-Elational Factor } & \multicolumn{5}{|c|}{ V.3 Dominant Learning Type } \\
\hline & & & 1.1 & 1.2 & 1.3 & 1.4 & 1.5 & 1.6 & 2.1 & 2.2 & 2.3 & 2.4 & 3.1 & 3.2 & 3.3 & 3.4 & 3.5 \\
\hline $\begin{array}{l}\text { Direzione Regionale } \\
\text { Musei Umbria }\end{array}$ & \#iorestoacasa & 157 & 84 & 18 & 20 & 12 & 23 & 0 & 18 & 0 & 3 & 136 & 17 & 124 & 3 & 1 & 12 \\
\hline $\begin{array}{l}\text { Museo Archeologico } \\
\text { Nazionale di Venezia }\end{array}$ & $\begin{array}{l}\text { \#Minimamiribilia } \\
\text { \#MonetaSonante } \\
\text { \#Supiazzadal1596 }\end{array}$ & 22 & 8 & 9 & 0 & 0 & 5 & 0 & 9 & 0 & 0 & 13 & 0 & 20 & 0 & 0 & 2 \\
\hline $\begin{array}{l}\text { Museo Archeologico } \\
\text { Sardinia (Cagliari) }\end{array}$ & $\begin{array}{l}\text { \#Archeobuongiorno } \\
\text { \#racconti } \\
\text { \#Laculturanonsiferma }\end{array}$ & 109 & 70 & 2 & 0 & 28 & 1 & 8 & 2 & 0 & 0 & 107 & 0 & 97 & 1 & 2 & 9 \\
\hline Museo Lavinium & $\begin{array}{l}\text { \#ArcheoDeltagli } \\
\text { \#Laculturanonsiferma }\end{array}$ & 20 & 18 & 0 & 0 & 0 & 1 & 1 & 0 & 0 & 0 & 20 & 0 & 19 & 0 & 0 & 1 \\
\hline Sistema Museo & \#Umbria & 12 & 8 & 0 & 0 & 0 & 2 & 2 & 0 & 0 & 0 & 12 & 0 & 10 & 0 & 0 & 2 \\
\hline $\begin{array}{l}\text { Parco Archeologico } \\
\text { di Ostia Antica }\end{array}$ & \#iorestoacasa & 18 & 9 & 0 & 0 & 1 & 7 & 1 & 0 & 0 & 0 & 18 & 0 & 17 & 0 & 0 & 1 \\
\hline Polo Napoli & \#iorestoacasa & 18 & 18 & 0 & 0 & 0 & 0 & 0 & 0 & 0 & 0 & 18 & 0 & 18 & 0 & 0 & 0 \\
\hline \multirow[t]{3}{*}{ Pompeii Sites } & \#Pompei \#Pompeii & 13 & 6 & 0 & 0 & 2 & 0 & 5 & 0 & 0 & 0 & 13 & 0 & 9 & 0 & 0 & 4 \\
\hline & & 395 & 227 & 33 & 22 & 44 & 51 & 18 & 29 & 0 & 7 & 359 & 17 & 331 & 9 & 4 & 34 \\
\hline & & $\%$ & 57.47 & 8.4 & 5.57 & 11.14 & 12.91 & 4.56 & 7.34 & 0 & 1.77 & 90.89 & 4.3 & 83.8 & 2.28 & 1.01 & 8.6 \\
\hline
\end{tabular}


From the perspective of comparative analysis, although activity was greater at Spanish institutions, the results do not show significant changes. (see Table 4). Of the 31 institutions from the Spanish sample, only $10(32.2 \%)$ carried out planned activity throughout the lockdown. Some institutions chose hashtags that were popular across the globe to share cultural content in their respective languages: \#Yomequedoencasa or \#LaCulturaEnTuCasa. Others preferred to adapt the message to their own brand by creating an original hashtag with its own identity such as \#AltamiraDesdeCasa (Museo de Altamira) or \#elMNATenCasa (Museo Nacional de Arqueología de Tarragona).

Table 4. Comparison between Italian and Spanish institutions activity during their lockdown.

\begin{tabular}{|c|c|c|c|c|c|c|c|c|c|c|c|c|c|c|c|c|}
\hline \multirow{2}{*}{ Country } & \multirow{2}{*}{ Tweets } & \multicolumn{6}{|c|}{ V.1 Purpose of the Message } & \multicolumn{4}{|c|}{ V.2 R-Elational Factor } & \multicolumn{5}{|c|}{ V.3 Dominant Learning Type } \\
\hline & & 1.1 & 1.2 & 1.3 & 1.4 & 1.5 & 1.6 & 2.1 & 2.2 & 2.3 & 2.4 & 3.1 & 3.2 & 3.3 & 3.4 & 3.5 \\
\hline \multirow{2}{*}{ Italy } & 395 & 227 & 33 & 22 & 44 & 51 & 18 & 29 & 0 & 7 & 359 & 17 & 331 & 9 & 4 & 34 \\
\hline & $\%$ & 57.47 & 8.4 & 5.57 & 11.14 & 12.91 & 4.56 & 7.34 & 0 & 1.77 & 90.89 & 4.3 & 83.8 & 2.28 & 1.01 & 8.61 \\
\hline \multirow[t]{2}{*}{ Spain } & 1177 & 671 & 210 & 78 & 80 & 138 & 0 & 133 & 23 & 50 & 971 & 131 & 629 & 64 & 67 & 286 \\
\hline & $\%$ & 57 & 17.84 & 6.63 & 6.8 & 11.72 & 0 & 11.3 & 1.95 & 4.25 & 82.5 & 11.13 & 53.44 & 5.44 & 5.69 & 24.3 \\
\hline
\end{tabular}

Upon further analysis, it is evident that for variable V.1, the objective of the message, the predominant goal for both cases was purely informative (i1.1) at over $50 \%$ of the messages in an almost exact interval. Both countries exceeded $57 \%$ of the tweets posted (898 of the 1572 analyzed), which announced formal aspects of the different collections. This purpose is closely linked to the absence of initiatives that motivate or provoke interaction between users or between users and institution, which prevents the development of a greater number of R-elational initiatives in the second variable. Some figures stood out for each case in the table above. For the Spanish institutions, it was the participatory (i1.2) and understanding (i1.3) objectives, which encouraged users to participate and provided them with hints to understanding the heritage and, thus, promote contemplation. As for the Italian institutions, the promotion of values and attitudes towards heritage (i1.4) and appreciation and transference (i1.5) stood out. Similarly noteworthy is item 1.6, which recorded the lack of a clear objective in the message; although infrequent, its presence was evident. The most notable figures were those that showed the greatest amount of variability. In Spanish institutions, citizen participation was encouraged to a larger extent, while in Italian institutions promoting the goal of sustainable heritage through awareness and appealing to the values of conservation, ownership, and respect was more prevalent.

Secondly, the 'R-elational Factor' (V.2) was analyzed with respect to the quantity and typology of participative initiatives the institutions tweeted. Despite being a 2.0 environment where interaction and the creative capacity of users is presumed, the lack of participative initiatives was surprising in both countries. This component was present in $9.11 \%$ of Italian institutions' tweets, while, thanks to the participative initiatives of two institutions which stood out throughout the study—the Alcazaba de Almería and the Museo Arqueologico Nacional-the value recorded for Spanish tweets was 17.5\%. It is important to note that among the few participative initiatives identified, the most frequently used strategy was interaction (7.34\% for Italy and $11.3 \%$ for Spain). Institutions took advantage of a 'survey' tool that Twitter provides account holders, which displays a series of options below a single question or comment, and users only have to click on the option they prefer.

Finally, in response to the prevailing type of learning present in each of the tweets (V.3), the high level of tweets with at least one suggested learning type allows us to consider these educommunicative environments, even if this alone does not qualify them as quality environments. Moreover, it cannot be overlooked that this sample was selected using a very reduced and specific time frame of just 2-3 months with sporadic hashtags, which favored the digital dimension due to the lockdown. The prevailing strategy in both countries has been termed cognitive (i3.2) capturing $83.8 \%$ of the analyzed tweets in Italy and $53.4 \%$ in Spain, which also displayed a high level of tweets with no proposed learning objective $(24.3 \%)$. This style of message is defined by the institution providing all the information it 
deems necessary about an item from its collection, while the user is not required to do any exploring or questioning, nor provide any further input apart from reading the information provided. Considering that the web 2.0 is an ideal environment for the construction of new learning paradigms and the interconnection between users and institutions, the limited number of messages where the prevailing type of learning was constructive (i3.3) or connective (i3.4) (2.28 and 1.01\% in Italy and 5.44 and 5.69\% in Spain, respectively) was negatively surprising.

\subsection{Archeological Institutions, SDGs, and Citizen Participation}

One of the key factors to achieving community involvement that strengthens heritage sustainability is that the citizenry establish connections through interaction. Considering that the fundamental agreements of the Sustainable Development Goals describe the need for an active and participative society, this study analyzed whether institutions in charge of archeology heritage in Italy and Spain were truly promoting and incentivizing citizen participation through interactive initiatives such as surveys, or exchange activities such as sharing experiences in museums by sending pictures and amateur models of specific artifacts produced at home. To analyze this factor, data which only reflect 'passive' participation were omitted since they did not expressly influence the message issued, such as a 'like' or 'sharing' information. The analysis focused on participative initiatives that show a clear R-elational factor (see Table 5). Namely, it focused on initiatives that imply explicit citizen participation to advance or achieve some goal—any request that the user take a specific action like voting, sending pictures, or giving their opinion, among others.

It is extremely remarkable that in a web 2.0 communicative environment, where interaction and co-creation by participants is presumed, the institutions scarcely incentivized users' active involvement. Italian institutions that did so represented less than $10 \%$ of the total. Only $9.11 \%$ of the tweets promoted some sort of active participation. The figures were somewhat higher for Spanish institutions (17.5\% of the tweets promoted active participation), although this was due entirely to the high level of activity carried out by two specific institutions: the Alcazaba de Almería and the Museo Arqueológico Nacional. This represents an important separation and a marked absence of this factor among the institutions. Evolution is necessary until a formula for connecting with the user and a common path for the participative goal of involvement and commitment to social awareness to reach the desired heritage sustainability can be found.

Among the limited number of participative initiatives, it is apparent that the institutions opted for interaction (i2.1) through the use of surveys or quizzes, both for the Italian institutions (7.34\% of tweets) and for the Spanish institutions (11.3\%). In both countries, there were nearly no reflexive initiatives (i2.2), which demonstrates that neither critical nor interpretive dimensions were encouraged. Finally, the reduced presence-though emergent and paramount—of truly co-creative initiatives (i2.3) that directly ask the user to undertake some activity based on a piece from the collection in a transformative, creative, or collaborative manner should be highlighted; there were only $1.77 \%$ in Italy and $4.25 \%$ in Spain.

To fully understand the sustainability factor, this study analyzed whether institutions in charge of archeology heritage are in line with respect for and conservation of heritage (Goal 11, target 4: "Strengthen efforts to protect and safeguard the world's cultural and natural heritage"). This goal is directly involved in achieving sustainability. The procedural sequence proposed by Fontal (2003) for heritage education is fundamental: to know, understand, value, respect, conserve, and transmit. To do so, we have used the values obtained from variable 1 "Heritage Education", indicator i1.4, "goal for ownership, care, and respect" by analyzing the tweets whose primary objective was to raise awareness of the need to care for, respect, and conserve heritage by making use of the hashtags from the sample (see Table 6). While the interaction component is responsible for creating the link, the prevailing objective in educational initiatives is key to raise awareness in the user. 
Table 5. Museums, Hastags during COVID-19, and R-elational factor to measure institutions' participative initiatives.

\begin{tabular}{|c|c|c|c|c|c|c|c|}
\hline \multirow[b]{2}{*}{ Country } & \multirow[b]{2}{*}{ Museum } & \multirow[b]{2}{*}{ Hashtag } & \multirow[b]{2}{*}{ Tweets } & \multicolumn{4}{|c|}{ V.2 R-Elational Factor } \\
\hline & & & & 2.1 Inter. & 2.2 Refl & 2.3 (Co) Cre & 2.4 There Is Not \\
\hline \multirow{10}{*}{ Italy } & $\begin{array}{l}\text { Direzione Regionale } \\
\text { Musei Umbria }\end{array}$ & \#iorestoacasa & 157 & 18 & 0 & 3 & 136 \\
\hline & $\begin{array}{l}\text { Museo Archeologico } \\
\text { Nazionale di Venezia }\end{array}$ & $\begin{array}{l}\text { \#Minimamiribilia } \\
\text { \#MonetaSonante } \\
\text { \#Supiazzadal1596 }\end{array}$ & 22 & 9 & 0 & 0 & 13 \\
\hline & $\begin{array}{l}\text { Museo Archeologico } \\
\text { Sardinia (Cagliari) }\end{array}$ & $\begin{array}{l}\text { \#Archeobuongiorno } \\
\text { \#racconti } \\
\text { \#Laculturanonsiferma }\end{array}$ & 109 & 2 & 0 & 0 & 107 \\
\hline & Museo Lavinium & $\begin{array}{l}\text { \#ArcheoDeltagli } \\
\text { \#Laculturanonsiferma }\end{array}$ & 20 & 0 & 0 & 0 & 20 \\
\hline & Sistema Museo & \#Umbria & 12 & 0 & 0 & 0 & 12 \\
\hline & $\begin{array}{l}\text { Parco Archeologico di } \\
\text { Ostia Antica }\end{array}$ & \#iorestoacasa & 18 & 0 & 0 & 0 & 18 \\
\hline & Polo Napoli & \#iorestoacasa & 18 & 0 & 0 & 0 & 18 \\
\hline & $\begin{array}{l}\text { museosmcv (Antica } \\
\text { Capua) }\end{array}$ & $\begin{array}{l}\text { \#viaggioinItalia } \\
\text { \#iorestoacasa }\end{array}$ & 26 & 0 & 0 & 4 & 22 \\
\hline & Pompeii Sites & \#Pompei \#Pompeii & 13 & 0 & 0 & 0 & 13 \\
\hline & & TOTAL & 395 & 29 & 0 & 7 & 359 \\
\hline \multirow{12}{*}{ Spain } & & & $\%$ & 7.34 & 0 & 1.77 & 90.89 \\
\hline & $\begin{array}{l}\text { Conjunto Monumental } \\
\text { Alcazaba de Almería }\end{array}$ & \#TuAlcazabaOnLine/\#AlcazabaOnline & 461 & 109 & 22 & 18 & 312 \\
\hline & $\begin{array}{l}\text { MARQ. Museo } \\
\text { Arqueológico de Alicante }\end{array}$ & \#quedateencasaconelMARQ & 181 & 0 & 0 & 0 & 181 \\
\hline & $\begin{array}{l}\text { Medina Azahara. } \\
\text { Conjunto Arqueológico }\end{array}$ & \#EnCasaConMedina & 45 & 0 & 0 & 0 & 45 \\
\hline & Museo Alhambra & \#TuMuseoOnLine & 36 & 0 & 0 & 0 & 36 \\
\hline & $\begin{array}{l}\text { Museo Arqueológico } \\
\text { Córdoba }\end{array}$ & \#QuedateEnCasa & 60 & 0 & 0 & 0 & 60 \\
\hline & Museo de Altamira & \#AltamiraDesdeCasa & 30 & 6 & 0 & 6 & 18 \\
\hline & $\begin{array}{l}\text { MAN. Museo } \\
\text { Arqueológico Nacional }\end{array}$ & \#MANSiempreCerca & 154 & 17 & 1 & 1 & 135 \\
\hline & $\begin{array}{l}\text { MNAR. Museo Nacional } \\
\text { de Arte Romano }\end{array}$ & \#EnCasaconelMNAR/\#LaCulturaEnTuCasa & 53 & 0 & 0 & 14 & 39 \\
\hline & $\begin{array}{l}\text { MNAT. Museu Nacional } \\
\text { Arqueologic de Tarragona }\end{array}$ & \#elMNATaCasa & 19 & 1 & 0 & 11 & 7 \\
\hline & $\begin{array}{l}\text { Museu de la història i de } \\
\text { la cultura de Mallorca. } \\
\text { (Pollentia) }\end{array}$ & \#MuseudeMallorcaDesdecasa & 138 & 0 & 0 & 0 & 138 \\
\hline & & TOTAL & 1177 & 133 & 23 & 50 & 971 \\
\hline & & & $\%$ & 11.3 & 1.95 & 4.25 & 82.5 \\
\hline
\end{tabular}


Table 6. Analysis of tweets in relation to SDG 11 "Cities" Goal 4 "Heritage".

\begin{tabular}{|c|c|c|c|c|c|}
\hline Country & Museum & Hashtag & Tweets & $\begin{array}{l}\text { SGDs.11 Cities } \\
\text { (Heritage) [V.1-1.4] }\end{array}$ & $\%$ \\
\hline \multirow{10}{*}{ Italy } & $\begin{array}{l}\text { Direzione Regionale Musei } \\
\text { Umbria }\end{array}$ & \#iorestoacasa & 157 & 12 & 7.64 \\
\hline & $\begin{array}{l}\text { Museo Archeologico Nazionale } \\
\text { di Venezia }\end{array}$ & $\begin{array}{l}\text { \#Minimamiribilia \#MonetaSonante } \\
\text { \#Supiazzadal1596 }\end{array}$ & 22 & 0 & 0 \\
\hline & $\begin{array}{l}\text { Museo Archeologico } \\
\text { Sardinia (Cagliari) }\end{array}$ & $\begin{array}{l}\text { \#Archeobuongiorno \#racconti } \\
\text { \#Laculturanonsiferma }\end{array}$ & 109 & 28 & 25.69 \\
\hline & Museo Lavinium & $\begin{array}{l}\text { \#ArcheoDeltagli } \\
\text { \#Laculturanonsiferma }\end{array}$ & 20 & 0 & 0 \\
\hline & Sistema Museo & \#Umbria & 12 & 0 & 0 \\
\hline & $\begin{array}{l}\text { Parco Archeologico } \\
\text { di Ostia Antica }\end{array}$ & \#iorestoacasa & 18 & 1 & 5.55 \\
\hline & Polo Napoli & \#iorestoacasa & 18 & 0 & 0 \\
\hline & museosmcv (Antica Capua) & \#viaggioinItalia \#iorestoacasa & 26 & 1 & 3.85 \\
\hline & Pompeii Sites & \#Pompei \#Pompeii & 13 & 2 & 15.38 \\
\hline & & TOTAL & 395 & 44 & $11.40 \%$ \\
\hline \multirow{11}{*}{ Spain } & $\begin{array}{l}\text { Conjunto Monumental Alcazaba } \\
\text { de Almería }\end{array}$ & \#TuAlcazabaOnLine/\#AlcazabaOnline & 461 & 72 & 15.62 \\
\hline & $\begin{array}{l}\text { MARQ. Museo Arqueológico } \\
\text { de Alicante }\end{array}$ & \#quedateencasaconelMARQ & 181 & 1 & 0.55 \\
\hline & $\begin{array}{l}\text { Medina Azahara. } \\
\text { Conjunto Arqueológico }\end{array}$ & \#EnCasaConMedina & 45 & 0 & 0 \\
\hline & Museo Alhambra & \#TuMuseoOnLine & 36 & 0 & 0 \\
\hline & Museo Arqueológico Córdoba & \#QuedateEnCasa & 60 & 0 & 0 \\
\hline & Museo de Altamira & \#AltamiraDesdeCasa & 30 & 2 & 6.67 \\
\hline & $\begin{array}{l}\text { MAN. Museo } \\
\text { Arqueológico Nacional }\end{array}$ & \#MANSiempreCerca & 154 & 2 & 1.3 \\
\hline & $\begin{array}{l}\text { MNAR. Museo Nacional } \\
\text { de Arte Romano }\end{array}$ & \#EnCasaconelMNAR/\#LaCulturaEnTuCasa & 53 & 1 & 1.89 \\
\hline & $\begin{array}{l}\text { MNAT. Museu Nacional } \\
\text { Arqueològic de Tarragona }\end{array}$ & \#elMNATaCasa & 19 & 1 & 5.26 \\
\hline & $\begin{array}{l}\text { Museu de la història i de la } \\
\text { cultura de Mallorca. (Pollentia) }\end{array}$ & \#MuseudeMallorcaDesdecasa & 138 & 1 & 0.72 \\
\hline & & TOTAL & 1177 & 80 & $6.80 \%$ \\
\hline
\end{tabular}

From the hashtags analyzed in Italy, the percentage of tweets that attempted to directly raise awareness of values like ownership, respect, and care for heritage was $11.4 \%$. In other words, at least one out of every ten tweets dealt directly with raising awareness of protecting and safeguarding heritage. The efforts of Museo de Cagliari and the official account for Pompeii stand out above the rest. By contrast, raising awareness about the value of protecting and caring for heritage was the objective of only $6.8 \%$ of the tweets analyzed in Spain. Only the Alcazaba de Almería carried out a consistent, planned strategy in this regards.

Finally, as a consequence of the public health crisis, the UN incorporated new areas of action called "COVID response" into Goal 4 from the SDGs "Ensure inclusive and equitable quality education and promote lifelong learning opportunities for all". These were created by the "Global Education Coalition: COVID-19 Education Response". There were three main areas of intervention proposed: (1) "help countries in mobilizing resources and implementing innovative and context-appropriate solutions to provide education remotely, leveraging hi-tech, low-tech and no-tech approaches", (2) "seek equitable solutions and universal access", and (3) "ensure coordinated responses and avoid overlapping efforts". All of the above are related, to a greater or lesser extent, to the educational response that institutions should implement digitally, which was the primary objective of this study. For this, we attempted to analyze the prevailing type of learning that the institutions promoted through their tweets in the selected hashtags to determine to what degree this remote learning and universal access response is being carried out (see Table 7). 
Table 7. Analysis of tweets in relation to prevailing learning type.

\begin{tabular}{|c|c|c|c|c|c|c|c|c|}
\hline \multirow[b]{2}{*}{ Country } & \multirow[b]{2}{*}{ Museum } & \multirow[b]{2}{*}{ Hashtag } & \multirow[b]{2}{*}{ Tweets } & \multicolumn{5}{|c|}{ Dominant Learning Type V.3 } \\
\hline & & & & 3.1 Behav. & 3.2 Cogn. & 3.3 Constr. & 3.4 Connect. & 3.5 There Is No \\
\hline \multirow{9}{*}{ Italy } & Direzione Regionale Musei Umbria & \#iorestoacasa & 157 & 17 & 124 & 3 & 1 & 12 \\
\hline & $\begin{array}{l}\text { Museo Archeologico Nazionale di } \\
\text { Venezia }\end{array}$ & $\begin{array}{l}\text { \#Minimamiribilia \#MonetaSonante } \\
\text { \#Supiazzadal1596 }\end{array}$ & 22 & 0 & 20 & 0 & 0 & 2 \\
\hline & Museo Archeologico Sardinia (Cagliari) & $\begin{array}{l}\text { \#Archeobuongiorno \#racconti } \\
\text { \#Laculturanonsiferma }\end{array}$ & 109 & 0 & 97 & 1 & 2 & 9 \\
\hline & Museo Lavinium & \#ArcheoDeltagli \#Laculturanonsiferma & 20 & 0 & 19 & 0 & 0 & 1 \\
\hline & Parco Archeologico di Ostia Antica & \#iorestoacasa & 18 & 0 & 17 & 0 & 0 & 1 \\
\hline & Polo Napoli & \#iorestoacasa & 18 & 0 & 18 & 0 & 0 & 0 \\
\hline & museosmcv (Antica Capua) & \#viaggioinItalia \#iorestoacasa & 26 & 0 & 17 & 5 & 1 & 3 \\
\hline & Pompeii Sites & \#Pompei \#Pompeii & 13 & 0 & 9 & 0 & 0 & 4 \\
\hline & & TOTAL & 395 & 17 & 331 & 9 & 4 & 34 \\
\hline & & & $\%$ & 4.3 & 83.8 & 2.28 & 1.01 & 8.61 \\
\hline \multirow{12}{*}{ Spain } & $\begin{array}{l}\text { Conjunto Monumental Alcazaba } \\
\text { de Almería }\end{array}$ & \#TuAlcazabaOnLine/\#AlcazabaOnline & 461 & 104 & 157 & 48 & 4 & 148 \\
\hline & $\begin{array}{l}\text { MARQ. Museo Arqueológico } \\
\text { de Alicante }\end{array}$ & \#quedateencasaconelMARQ & 181 & 0 & 94 & 2 & 1 & 84 \\
\hline & $\begin{array}{l}\text { Medina Azahara. Conjunto } \\
\text { Arqueológico }\end{array}$ & \#EnCasaConMedina & 45 & 0 & 45 & 0 & 0 & 0 \\
\hline & Museo Alhambra & \#TuMuseoOnLine & 36 & 1 & 33 & 0 & 0 & 2 \\
\hline & Museo Arqueológico Córdoba & \#QuedateEnCasa & 60 & 0 & 58 & 0 & 0 & 2 \\
\hline & Museo de Altamira & \#AltamiraDesdeCasa & 30 & 7 & 12 & 4 & 0 & 7 \\
\hline & MAN. Museo Arqueológico Nacional & \#MANSiempreCerca & 154 & 15 & 91 & 2 & 21 & 25 \\
\hline & MNAR. Museo Nacional de Arte Romano & \#EnCasaconelMNAR/\#LaCulturaEnTuCasa & 53 & 0 & 37 & 4 & 3 & 9 \\
\hline & $\begin{array}{l}\text { MNAT. Museu Nacional Arqueològic } \\
\text { de Tarragona }\end{array}$ & \#elMNATaCasa & 19 & 4 & 4 & 4 & 1 & 6 \\
\hline & $\begin{array}{l}\text { Museu de la història i de la cultura de } \\
\text { Mallorca. (Pollentia) }\end{array}$ & \#MuseudeMallorcaDesdecasa & 138 & 0 & 98 & 0 & 37 & 3 \\
\hline & & TOTAL & 1177 & 131 & 629 & 64 & 67 & 286 \\
\hline & & & $\%$ & 11.13 & 53.44 & 5.44 & 5.69 & 24.3 \\
\hline
\end{tabular}


By choosing only those hashtags with an ongoing educommunicative strategy for the time period analyzed, the percentages of tweets which included at least one type of prevailing learning were substantially high: $91.39 \%$ for Italian institutions and $75.7 \%$ for Spanish institutions. Despite this, it should not be overlooked that these percentages represent a tiny portion of the overall volume of existing institutions: only 19 institutions of the $72(26.39 \%)$ that recorded regular Twitter activity. However, the data was much more worrisome. Of the $\mathrm{n}=1117$ sites and institutions cataloged in official databases, only $n=185$ had an official account and have online visibility. This is the starting point to establish educommunicative strategies: having a digital environment. These 19 institutions represent $10.27 \%$ of the total comparative sample of $n=185$.

After analyzing the learning type, the results show that the prevailing activity was cognitive. Institutions simply provided information about a piece or an item from their collections, a very traditionalist and reductionist vision of the educational strategy: data transfer. This represented $53.44 \%$ of the tweets for Spanish institutions while it represented $83.8 \%$ for Italian ones. This indicator allows us to suggest, as was mentioned in Section 3.2, that cultural and museum institutions are, indeed, generating "opportunities for lifelong learning" (SDG 4), but for the moment only an extremely limited portion of the existing institutions do so. Those that were active, encouraged learning with relative frequency during this atypical situation where public places were forced to close, and online visits were the norm. Nevertheless, these emergent educommunicative strategies only allow us to talk about an initial state of activity in which institutions were being located, but not about quality activity that makes users aware of the heritage they possess. The ultimate goal of SDG 4 is quality education, and in order to achieve that, an improvement in educommunicative quality is necessary.

\section{Discussion}

UNESCO defines cultural heritage simultaneously as a good and a process which supplies society with a stream of resources inherited from the past, created in the present, and transmitted to future generations for their benefit [57]. Culture and museum institutions that originated from private collections and evolved into safeguarding, conservation, investigation, and dissemination have a "corporate social responsibility" [58]. This can be understood as a "set of actions that an organization strategically executes and communicates through discourse after assuming an active commitment to contribute to the well-being of the local and global environment in a voluntary, cross-cutting, and lasting manner, while integrating interest groups' visions, involving its sphere of influence, ensuring the sustainability of its corporate model, and achieving continuous improvement of its social, environmental, and economic actions [59]. It thereby clearly defines their social commitment as exhibitors.

Some global studies about institutions' counterparts, the recipient, such as The Social Media Family 2020 indicate that nearly 3.8 million internet users (of an online population of close to 4.5 million users) confirm they interact on at least one social network. To understand the magnitude of these figures we can compare them with global data: " $48 \%$ of the 7.75 billion inhabitants of planet Earth have a profile on at least one social network". That is to say, nearly half the planet has at least one account where they can interact [60].

In the context of this study, according to data from We Are Social and Hootsuite, in January 2020 there were 49.48 million internet users ( $82 \%$ of its population), 1.2 million more $(+2.4 \%)$ than in January of 2019. Regarding social networks, at the start of 2020 there were 35 million users, an increase of $6.4 \%$ year over year. This represents a penetration of social networks in Italy of 58\% [61]. In Spain, of a total population of 46.75 million, there were 42.4 million internet users (91\% of its population). The data show that around 29 million people are active on the web 2.0 , where $62 \%$ affirm spending two hours daily on social media networks, among them Twitter (53\%). Conversely, what is most striking, and at the same time dismaying, about the figures provided by the Spanish government [62], is that only 280,000 internet users ( $0.7 \%$ of the total population and $0.9 \%$ of internet users) confirm 
they regularly interact with museums, libraries, and monuments on social networks that is, the real consumers of culture. In this respect, some research [63] indicates demand for cultural goods must be answered with a holistic and attractive experience, a task which the same institutions responsible for protecting and promoting heritage must assume. In addition to these figures, the temporal nature of this study, which favors an increase in activity on social networks, should be taken into account. According to a monthly analysis of internet consumption at a global level, there was a $47 \%$ increase during the COVID-19 pandemic, although this same study confirms that social networks did not achieve a level of penetration of $50 \%$ of the population [64]. This study asserts there was a $7.4 \%$ increase in (321 million additional) internet users between the months of October 2019 and January 2020 and a $12.3 \%$ increase in the active use of social networks (453 million additional users). As reported by the authors of these studies, these figures indicate the largest increase since this data collection began in 2011 [60] and demonstrate that cultural and museum institutions have been able to reach not only a larger overall market due to the increased level of users, but also a market which has been using social networks for a longer period of time. If demand and the number of visitors increases, institutions need to respond, not only quantitatively, but qualitatively. It is not a question of posting better numbers, rather they must create a connection, significant learning, and a commitment to heritage sustainability.

Before this study, we started from figures analyzed in the ICOM report [35] of November 2020 , which indicates that $47 \%$ of the museums analyzed maintained their activity on social networks; $41.9 \%$ claim to have increased their activity; and $3.8 \%$ confirmed that they had started their presence on social networks as a result of the forced closure. Based on these statistics, we thought that practically all the institutions would be present in the network and a significant percentage would be active, however, the results have been far from this hypothesis, although they have expanded their educational offer in some cases. Quantitatively, most regions opted for the use of previous digital resources and greater activity on social networks, although it is worth highlighting the effort in Western Europe and North America to create new activities during confinement [33]. Effort rewarded by the significant increase in online visits where the most visited content has been the social networks of the museums and educational materials [36].

Continuing with the analysis of digital spaces, the institutions analyzed in the ICOM report [35] state that $21.8 \%$ have staff dedicated full time to digital activities, while $56.8 \%$ have staff dedicated to digital content but not full time. Economically, $29.4 \%$ of museums dedicate between 1 and $5 \%$ of their budget to digital content, $14.9 \%$ of museums between 6 and $10 \%$, and $12 \%$ of institutions more than $10 \%$. On the other hand, $19.7 \%$ dedicate less than $1 \%$ of the budget to digital activities. [35]. Of these figures, according to the study carried out by Network of European Museums Organizations (NEMO), 3 out of 5 museums have suffered losses of EUR 20,300 per week during confinement, which has had a direct impact on the hiring of staff or the forced end of collaborations with volunteer programs [36]. Currently, $74.8 \%$ of the institutions are considering increasing the digital offer and $76.6 \%$ are considering rethinking their strategy [35]. This shows, from our point of view, a clear awareness and possibly the beginning of a new stage in museum web 2.0 educommunication. It is also interesting to know that $17.6 \%$ of the institutions have started an online learning offer as a result of the confinement [35], something that should be observed, quantified, and analyzed in future research that from this line of research is already underway developing out internationally.

Although the report makes it clear that absolutely not all museum actions have been counted, the report prepared by UNESCO has counted more than 800 actions by museums in response to the crisis throughout the planet, demonstrating the importance of use of information and communication technologies for the sector, which has allowed them to transform many of the activities planned for 2020, from conferences to exhibitions, to digital format. Of these more than 800 actions, 27.4\% were produced in Latin America and the Caribbean, 26.6\% in Western Europe and others, 20.3\% in Asia and the Pacific, $16.6 \%$ in Eastern Europe, $7 \%$ in Arab countries, and 2.1\% in Africa [33]. 
Following isolated measures taken by some Chinese institutions due to physical closures in response to the public health crisis, Italian museums were the first to promote official platforms on the web 1.0 and 2.0 [22]. Some of the initiatives included virtual visits, short videos made with drones in empty spaces with a mix of filming resources, and the use of humor in the museum of Venice, which, in connection with the past, was recorded using period masks that were also used to avoid contagion. Although Italian museums significantly increased their activity on Twitter in general [22], of the institutions included in the sample only those that were previously using Twitter, such as the Direzione Regionale di Musei Umbria, the Museo Archeologico Nazionale di Venezia, and the Museo Archeologico Sardegna, displayed truly consistent and organized activity. Although analysis of social networks was not an objective of the present study, it comprises this line of research. After observing social networks as a whole, it is evident that COVID-19 was a significant boost for the Italian culture and museum institutions that decidedly bet on carrying out their activity on Instagram or Facebook, leaving Twitter for specific actions, such as Museum Week, where they had already been participating assiduously.

Some studies on the most frequently used apps indicated in 2016 that the use of Twitter in Italy was far from the top five, namely it was in 17th position in comparison to 2nd for Facebook [23]. Other authors [63] indicated that exchange between museums and their visitors was not sufficiently open (2017). However, Spain has a five or six-year track record with this social network, which could partly explain the difference in the figures obtained from the comparative analysis. Spanish museums have not 'abandoned' Twitter as an educommunicative environment, although it is primarily used for information or advertising. The first benchmark studies conducted in Spain on museums and the internet, "lazos de luz azul" [65] and "La Educación Patrimonial. Teoría y Práctica en el Aula, el Museo e Internet" [48], indicated beginnings focused on advertising and dialogue, and the need for truly educommunicative strategies [66]. Moreover, some Spanish museums have been posting on networks like Facebook with the same frequency and of the same quality as has been the norm across the globe [67]. Archeology institutions had been slowly entering the web 2.0 environment [11] until the point where it has now become a fundamental part of their communication plans and strategies [68]. In addition to this wellestablished track record on Twitter, the human component must be considered: personal initiative. Museum personnel at some institutions have designed and implemented their own educommunicative strategies without any limitations, either by themselves or with the help of teams where economic and human constraints have permitted [39,68]. Globally, and with a lack of more conclusive studies, institutions have attempted to adapt to the physical closures in two ways. First, they have assured museum staff of their viability in the short term $[69,70]$. Second, they have viewed the situation as an opportunity to create a new channel for delivery to internet users [71].

Purely analytical studies indicate that without metrics to measure the capacity and results achieved by institutions regarding engagement, it is clear that British and American institutions have made a concerted effort to provide a larger quantity, higher quality, and greater variety of content for their followers, as well as for future visitors [29].

The SDGs and the 2030 Agenda, together with citizen participation, fit perfectly in the web 2.0 ecosystem. The web 2.0 is defined as an open and participative web [72] where the presumption is that users become exhibitors and recipients at the same time, termed "emirec" [73] in the same fashion as "prosumer". Although the genesis of this concept is in economics, contributions from authors like Henry Jenkins [74] helped to develop it from the perspective of transmedia storytelling to describe users that not only receive or exhibit information they deem relevant, but also take the leap to a new generation of content.

In view of the limited examples where institutions called for a connection among their followers to generate forums to exchange information, experiences, etc., an interesting proposal would be for institutions to explore a communicative strategy where "Formidling" is greatly enhanced. Danish museums use this term to express a "connection between two parties", and in the museum field this is understood not only as the action of transmitting, 
but also as a reciprocal exchange, interpretations of meanings, and (inter)actions and exchange [25].

In light of the results obtained, it is clear that the institutions analyzed that still use Twitter as an educommunicative environment aim to increase awareness of respect and care for heritage, although not as a matter of priority $[3,75,76]$, except in cases where the official account belongs to an open-air site such as Pompeii or the Alcazaba de Almería.

Finally, we can conclude that the institutions analyzed, though they represent only a small percentage of the total number listed, have committed to truly educommunicative initiatives consistent with the established SDGs and COVID goals during the first phase of the public health crisis. Additional studies are needed to determine whether this commitment to remote learning in the face of physical closures will pay dividends in the form of higher numbers of followers and feedback; likewise, more studies are needed to ascertain whether heritage institutions can serve as the driving force for the emergence and strengthening of heritage cyber communities.

\section{Conclusions}

Since the Faro Convention [77], the concept of heritage communities has been defined as "people who value specific aspects of cultural heritage which they wish, within the framework of public action, to sustain and transmit to future generations" (p. 2). We believe that introducing or transferring this concept to the web 2.0 enables us to talk about heritage cyber communities $[4,6,11]$ where we not only consider safeguarding or promoting heritage but also a transcendental experience of lifelong learning through the exchange of information and opinions in an online context [7], characterized by the interconnectivity and the preeminence of the ephemeral. While this seems to be contrary to "lifelong learning", it should be seen as an opportunity for a museum to diversify its offer, not only in terms of promotion (exhibitions, news, etc.) but also in terms of possible themes or proposed collaborative actions (sharing memories in the museum, carrying out actions to transform the space by proposing new pieces, etc.) and encouraging co-creation processes [8].

The first benchmark studies conducted in Spain $[48,65]$, allow us to verify that current dynamics show how institutions dominate language on networks thanks to ongoing training and the specialization of museum staff. However, due to time constraints [66], on many occasions these individuals have to carry out educommunication which is chiefly advertising in nature; institutions simply give notice of upcoming expositions, workshops, and activities.

Some of the museum proposals observed by the UNESCO report [33] have been: the use of previous digital resources, the digitization of activities already programmed to be used during the lockdown, increasing activity on social networks, the creation of specific activities for the lockdown, the organization of professional and scientific activities during the lockdown, etc. This concern for good practices should not remain as a watertight element when a physical closure occurs in the face of a supervening situation, this has only been the prelude to a change that needs to undergo a process of transformation and adaptation throughout the planet. The museum offer has already started a process that will increase its digital offer by adding more digital resources and tools, but which is still in a very incipient field to achieve outstanding educommunication. To highlight some specific initiatives, Zürich's Museum of Digital Art (MuDA) offered streaming classes titled "Creative Corona Classes" divided by age, language, and subject. The Thyssen Museum in Spain for example opted to digitize the exhibition scheduled for 2020 "Rembrandt and Amsterdam portraiture, 1590-1760" also complementing it with an immersive experience for users through the use of audio guides. The museum itself has reported an increase in visits of 56\% during the period between 13 March and 13 April 2020 compared to the same period in 2019 [36].

We cannot forget the fundamental role that museums play in promoting and developing social and tourism, making these institutions an indispensable engine in the 
development of sustainable cultural and economic policies at both the local and national levels [33]. This new situation has shown that online content is an absolutely fundamental extension and complement of the physical museum. Museums are not islets isolated from each other, precisely in times of crisis is when it is necessary to bet on transnational collaborations that allow learning from each other [36]. For this reason, this study is just one example that allows us to know the activity of the countries in order to know the weaknesses and strengths that each one contributes as references of an educommunication that prevails today.

Interestingly, the third most serious threat to the institution according to those surveyed, after not being able to reopen or not being able to attract new visitors, is losing contact with the [35] community, something that web 2.0 allows to keep active and whose lines of action must be adequate, meaningful, and professionally outlined in order to achieve the social and educational objectives that are fundamental pillars of cultural institutions. Some lines of action that the ARGOS research group has been working on through the analysis of educommunication and the emergence of new delocalized patrimonial cybercommunities thanks to the characteristics of the digital world [11,39-41,78].

Certainly, museum visibility on social networks through the creation of official accounts has allowed these institutions to penetrate users' daily lives and offer them the opportunity to access museum content at any time and from any place [79]. However, they seem to have forgotten that web 2.0 platforms like Twitter were designed to be guided by nodes of interest [80] avoiding being imbued with the rhizomatic model of knowledge transmission [81], which is so characteristic of Twitter. It is difficult to find examples of institutions that, mirroring society's intellectual demands, propose activities or new themes to facilitate forums for discussion. This places us close to educommunication but not yet to the point of awareness and the signification of interactions. We are on the right path, but there is still a long way to go. Italian archeology museums on Twitter, in general, do not constitute a R-elational and participative educommunicative environment. Rather, they continue to participate on the web 2.0 as mere exhibitors of the content they possess, bringing to mind that primal function of safeguarding and exhibiting; they do manage to incorporate the SDGs into their educommunicative objectives, at least more so than do Spanish museums. Moreover, two issues should be noted. Firstly, the present study focused only on Twitter, so it cannot be implied that this educommunication is being carried out differently on other social media networks. Secondly, the sustainability and participation components were only met thanks to a few benchmark institutions that made a difference. Consequently, the landscape was not homogeneous in this regards. The institutions analyzed continue to participate on the web 2.0 as mere exhibitors of the content they possess bringing to mind that primal function of safeguarding and exhibiting.

The objective is far from being met. An equilibrium between the parties must be reached, but, presently, we face highly insufficient results that must be improved in order to achieve quality standards and respond to social and technological demands. The SDGs analyzed in the present study-opportunities for lifelong learning, care and protection of heritage, and citizen participation — can and must be the three fundamental axes in future educommunicative plans of the culture and museum institutions on Twitter.

Only if institutions work to achieve the sequences that refer to respect, care, and ownership can true global awareness for protecting and safeguarding the cultural and natural heritage of the world be created. Raising awareness through these objectives, establishing links through interaction, and engaging users through learning are absolutely necessary in this educommunicative chain.

Author Contributions: Conceptualization, I.N.-N., P.R., and S.G.-C.; methodology, I.N.-N. and S.G.-C.; software, I.N.-N.; validation, P.R. and S.M.-P.; formal analysis, I.N.-N.; investigation, I.N.N. and S.G.-C.; data curation, I.N.-N.; writing-original draft preparation, I.N.-N. and S.G.-C.; writing-review and editing, P.R., S.G.-C., and S.M.-P.; visualization, S.G.-C.; supervision, P.R.; project administration, P.R. and S.M.-P.; funding acquisition, P.R. and S.M.-P. All authors have read and agreed to the published version of the manuscript. 
Funding: This research was funded by Government of Aragón and European Regional Development Fund (ERDF), grant number RISS3-LMP18_18 “ARAGÓN OPEN AIR MUSEUM (2014-2020 Construyendo Europa desde Aragón)". Besides, this research was funded by the Spanish Ministry of Science, Innovation and Universities and EU's ERDF grant number EDU2016-78163-R “Educomunicación web 2.0 del patrimonio". Moreover, this research was funded by University institute for Research in Environmental Sciences of Aragon (IUCA) and Research Group ARGOS, grant number (S50_20R) and by Research Grants to Meet Specific Needs of the University of Murcia, Modality I, granted by Rectoral Resolution of the 11/03/2019 (R-1208/2019). The funders of this research have had no role in the design of the study; in the collection, analyses, or interpretation of data; in the writing of the manuscript, or in the decision to publish the results.

Institutional Review Board Statement: Not applicable.

Informed Consent Statement: Not applicable.

Data Availability Statement: Not applicable.

Acknowledgments: This article has been possible thanks to the project RISS3-LMP18_18 OPEN AIR MUSEUM (Government of Aragon and ERDF 2014-2020 "Building Europe from Aragon"), to the research project EDU2016-78163-R “Web 2.0 educommunication of heritage" (Ministry of Science, Innovation and Universities of Spain and ERDF), the research group ARGOS, the didactics of social sciences, that has the support of the Government of Aragon, FEDER (EU)-Fondo Europeo de Desarrollo Regional- 2014-2020 and the University Institute of Research in Environmental Sciences of Aragon (IUCA) of the University of Zaragoza. And to the Research Grants to Meet Specific Needs of the University of Murcia, Modality I, granted by Rectoral Resolution of the 11/03/2019 (R-1208/2019).

Conflicts of Interest: The authors declare no conflict of interest.

\section{References}

1. Marta-Lazo, C.; Gabelas, J.A. Comunicación Digital. Un Modelo Basado en el Factor Relacional; Editorial UOC: Barcelona, Spain, 2016.

2. Lladó-Morales, M.; Atenas, J. La interactividad y la Web. In Manual de Museografía Interactiva; Santacana, J., Martín-Piñol, C., Eds.; Edicions Trea: Gijón, Spain, 2010; pp. 337-368.

3. Pescarin, S.; Cerato, I.; Romi, P. Virtual museums and social networks. In Proceedings of the 2016 IEEE 2nd International Forum on Research and Technologies for Society and Industry Leveraging a Better Tomorrow, RTSI, Bologna, Italy, 7-9 September 2016; IEEE: Piscataway, NJ, USA, 2016.

4. Jones, Q. Virtual-Communities, Virtual Settlements \& Cyber-Archaeology: A Theoretical Outline. JCMC 1997, 3, 3. [CrossRef]

5. Harrison, R. Excavating Second Life: Cyber-Archaeologies, Heritage and Virtual Communities. J. Mater. Cult. 2009, 14, 75-106. [CrossRef]

6. Watrall, E. Building Scholars and Communities of Practice in Digital Heritage and Archaeology. Adv. Archaeol. Pract. 2019, 7, 140-151. [CrossRef]

7. Marchetti, N.; Angelini, G.I.; Artioli, G.; Benati, G.; Bitelli, G.; Curci, A.; Marfia, G.; Roccetti, M. NEARCHOS. Networked Archaeological Open Science: Advances in Archaeology through Field Analytics and Scientific Community Sharing. J. Archaeol. Res. 2018, 26, 447-469. [CrossRef]

8. Rubio, N.; Villaseñor, N.; Yagüe, M. Sustainable co-creation behavior in a virtual community: Antecedents and moderating effect of participant's perception of own expertise. Sustainability 2020, 12, 19. [CrossRef]

9. De La Peña Aznar, J. ¿Sirven para algo las redes sociales en el sector cultural? Anu. AC/E Cult. Digit. Tema 2014, 8, 101-113.

10. Chiappe, A.; Arias, V. La educomunicación en entornos digitales: Un análisis desde los intercambios de información. Opción 2016, 32, 461-479.

11. Rivero, P.; Navarro-Neri, I.; García-Ceballos, S.; Aso, B. Spanish Archaeological Museums during COVID-19 (2020): An Educommunicative Analysis of Their Activity on Twitter through the Sustainable Development Goals. Sustainability 2020, 12, 8224. [CrossRef]

12. United Nations Educational, Scientific and Cultural Organization. Education for Sustainable Development Goals—Learning Objectives, France, 2017. Available online: https://unesdoc.unesco.org/ark:/48223/pf0000247444?utm_sq=gj34xbfn94 (accessed on 28 January 2021).

13. Pierroux, P.; Bäckström, M.; Brenna, B.; Gowlland, G.; Ween, G.B. Museums as Sites of Participatory Democracy and Design. In $A$ History of Participation in Museums and Archives. Traversing Citizen Science and Citizen Humanities; Hetland, P., Pierroux, P., Esborg, L., Eds.; Routledge: London, UK, 2020; pp. 27-45.

14. Fernández, E.G.; Alarcón, E.V.; Valcarcel, A.S. Tourist functionality of the communication management on malaga's museums' social networks. [Funcionalidad turística de la gestión de la comunicación en redes sociales de museos de málaga]. Doxa Comun. 2020, 30, 309-330. [CrossRef] 
15. Myna, Z.; Banakh, V.; Nahirnyak, A.; Iavich, M. Analysis of the essence of social networks as a tool for mediatization of the historical and cultural heritage of museums. CEUR Workshop Proc. 2020, 2616, 199-213.

16. Claes, F.; Deltell, L. Museo social en España: Redes sociales y webs de los museos estatales. Prof. Inf. 2019, 28, e280304. [CrossRef]

17. Gómez-Vílchez, S. Museos españoles y redes sociales. Telos Cuad. Comun. Innov. 2012, 90, 79-86.

18. Gómez-Vílchez, S. Debates culturales a través de Twitter. Rev. PH 2014, 86, 9-10. [CrossRef]

19. Cordón-Benito, D.; González-González, D. Museos y comunicación: Los nuevos medios como herramienta de diálogo y sociabilidad de la institución. El uso de Twitter por el Museo del Prado, Museo Thyssen-Bornemisza y Museo Reina Sofía". Fonseca 2016, 12, 149-165. [CrossRef]

20. Viñarás-Abad, M.; Caerols-Mateo, R. Redes sociales y patrimonio: Cinco museos especializados. Opción 2016, 32, 968-988.

21. Capriotti, P.; Losada-Díaz, J.C. Facebook as a dialogic communication tool at the most visited museums of the world. Prof. Inf. 2018, 27, 642-650. [CrossRef]

22. Agostino, D.; Arnaboldi, M.; Lampis, A. Italian state museums during the COVID-19 crisis: From onsite closure to online openness. Mus. Manag. Curatorship 2020, 35, 362-372. [CrossRef]

23. Zuanni, C. Italian Museums and Twitter: An analysis of Museum Week. Archeostorie J. Public Archaeol. 2017, 1, 119-133. [CrossRef]

24. Lazzeretti, L.; Sartori, A.; Innocenti, N. Museums and social media: The case of the Museum of Natural History of Florence. Int. Rev. Public Nonprofit Mark 2015, 12, 267-283. [CrossRef]

25. Holdgaard, N.; Ekelund-Simonsen, C. Attitudes towards and conceptions of digital technologies and media in Danish museums. MedieKultur 2011, 50, 100-118. [CrossRef]

26. Trolle-Gronemann, S.; Kristiansen, E.; Drotner, K. Mediated co-construction of museums and audiences on Facebook. MMC 2015, 30, 174-190. [CrossRef]

27. Fernandes, A.B. "But will there be visitors?" Public outreach efforts using social media and online presence at the Côa Valley Museum and Archaeological Park (Portugal). Internet Archaeol. 2018, 47. [CrossRef]

28. Zyglidopoulos, S.; Symeou, P.C.; Bantimaroudis, P.; Kampanellou, E. Cultural Agenda Setting: Media Attributes and Public Attention of Greek Museums. Commun. Res. 2012, 39, 480-498. [CrossRef]

29. Samaroudi, M.; Rodriguez-Echavarria, K.; Perry, L. Heritage in lockdown: Digital provision of memory institutions in the UK and US of America during the COVID-19 pandemic. MMC 2020, 35, 337-361. [CrossRef]

30. Kidd, J. Enacting engagement online: Framing social media use for the museum. Inf. Technol. People 2011, 24, 64-77. [CrossRef]

31. Garner, A.; Goldberg, J.; Pou, R. Collaborative Social Media Campaigns and Special Collections: A case study on \#ColorOurCollections. RBM J. Rare Books Manuscr. Cult. Herit. 2016, 17, 100-117.

32. Fletcher, A.; Lee, M.J. Current social media uses and evaluations in American museums. MMC 2012, 27, 505-521. [CrossRef]

33. UNESCO. Museums around the World. In the Face of Covid-19. France, May 2020. Available online: https://unesdoc.unesco. org/ark:/48223/pf0000373530 (accessed on 27 January 2021).

34. UNESCO. Recommendation concerning the Protection and Promotion of Museums and Collections, their Diversity and their Role in Society. France, November 2015. Available online: https:/ / unesdoc.unesco.org/ark:/48223/pf0000246331 (accessed on 27 January 2021).

35. ICOM. Informe: Museos, Profesionales de los Museos y COVID-19: Encuesta de Seguimiento. France, November 2020. Available online: https:/ / icom.museum/wp-content/uploads/2020/11/FINAL-ES_Follow-up-survey.pdf (accessed on 27 January 2021).

36. NEMO. Survey on the Impact of the COVID-19 Situation on Museums in Europe. Final Report. Germany, May 2020. Available online: https://www.ne-mo.org/fileadmin/Dateien/public/NEMO_documents/NEMO_COVID19_Report_12.05.2020.pdf (accessed on 27 January 2021).

37. Bliss, A.M. Image for the Future of the Historic City: Photo-Elicitation and Architectural Preservation in Barcelona. In HumanCentered Built Environment Heritage Preservation: Theory and Evidence-Based Practice; Wells, J.C., Stiefel, B.L., Eds.; Routledge: New York, NY, USA, 2019; pp. 129-142.

38. Grimal, P. Diccionario de Mitología Griega y Romana; Editorial Labor: Barcelona, Spain, 1951.

39. Aso, B.; García-Ceballos, S.; Rivero, P. La educomunicación web 2.0 de los museos en la sociedad digital. In Re_Visiones Sobre Arte, Patrimonio y Tecnología en la era Digital; Baldellou, F.C., Irala-Hortal, P., Eds.; Zaragoza: Gobierno de Aragón, Spain, 2019; pp. 339-345.

40. Navarro-Neri, I.; Rivero, P. Los principales museos arqueológicos españoles en las redes sociales: Estudio exploratorio sobre procesos educomunicativos. Ens. Rev. Fac. Educ. Albacete 2019, 34, 163-178. [CrossRef]

41. Rivero, P.; Navarro-Neri, I.; Aso, B. Educommunication Web 2.0 for heritage: A view from Spanish museums. In Handbook of Research on Citizenship and Heritage Education; Delgado-Algarra, E.J., Cuenca-López, J.M., Eds.; IGI Global: Hershey, PA, USA, 2020; pp. 450-471.

42. Ibañez-Etxeberria, Á.; Gómez-Carrasco, C.J.; Fontal, O.; García-Ceballos, S. Virtual Environments and Augmented Reality Applied to Heritage Education. An Evaluative Study. Appl. Sci. 2020, 10, 2352. [CrossRef]

43. Mckeague, P.; Veer, R.; Huvila, I.; Moreau, A.; Verhagen, P.; Bernard, L.; Cooper, A.; Green, C.; Manen, N. Mapping Our Heritage: Towards a Sustainable Future for Digital Spatial Information and Technologies in European Archaeological Heritage Management. JCAA 2019, 2, 89-104. [CrossRef]

44. Centro del Patrimonio Mundial. Available online: https://whc.unesco.org/es/list/ (accessed on 17 November 2020). 
45. Naciones Unidas. “Objetivo 4: Garantizar una Educación Inclusiva, Equitativa y de Calidad y Promover Oportunidades de Aprendizaje Durante toda la Vida para Todos" 2015. Available online: https://www.un.org/sustainabledevelopment/es/ education/ (accessed on 15 November 2020).

46. Naciones Unidas. Objetivo 11: Lograr que las Ciudades Sean más Inclusivas, Seguras, Resilientes y Sostenibles. 2015. Available online: https://www.un.org/sustainabledevelopment/es/cities/ (accessed on 15 November 2020).

47. Marta-Lazo, C.; Marfil-Carmona, R.; Hergueta-Covacho, E. Aplicación de las Redes Sociales en el aprendizaje en conectividad: Uso del factor relacional en la dialéctica twitter. Rev. Cient. Electron. Educ. Comun. Soc. Conoc. 2016, 16, 2. [CrossRef]

48. Fontal, O. La Educación Patrimonial. Teoría y Práctica en el Aula, el Museo e Internet; Ediciones Trea: Gijón, Spain, 2003.

49. UNESCO; UNICEF; The World Bank; UNFPA; UNDP; UN Women; UNHCR. Education 2030: Incheon Declaration and Framework for Action for the implementation of Sustainable Development Goal 4: Ensure inclusive and equitable quality education and promote lifelong learning opportunities for all. ED-2016/WS/28 W. Proceedings of The World Education Forum 2015, Incheon, Korea, 19-22 May 2015; Available online: https:/ / unesdoc.unesco.org/ark:/48223/pf0000245656 (accessed on 16 November 2020).

50. UNESCO. Policy document on world heritage and sustainable development. The General Assembly of States Parties to the World Heritage Convention; France, 2015; pp. 1-18. Available online: https://whc.unesco.org/en/sustainabledevelopment/ (accessed on 16 November 2020).

51. Roche, S. Learning for life, for work, and for its own sake: The value (and values) of lifelong learning. Int. Rev. Educ. Springer 2017, 63, 623-629. [CrossRef]

52. Juanals, B.; Minel, J. Information flow on digital social networks during a cultural event: Methodology and analysis of the "european night of museums 2016" on twitter. In Proceedings of the 8th International Conference on Social Media \& Society, Part F129683. Toronto, ON, Canada, 28-30 July 2017. [CrossRef]

53. Villaespesa, E. Diving into the Museum's Social Media Stream. Analysis of the Visitor Experience in 140 Characters. In Museums and the Web 2013; Proctor, N., Cherry, R., Eds.; Museums and the Web: Silver Spring, MD, USA, 2013; Available online: https:/ / mw2013.museumsand theweb.com/paper/diving-into-the-museums-social-media-stream/ (accessed on 16 November 2020) un-published.

54. Gabás, R. Análisis de Actividad en Redes Sociales, End-of-degree Project; Universidad de Zaragoza: Zaragoza, Spain, 2019; unpublished.

55. Pinna, G. La Europa del sur y sus museos: El caso de Italia. Rev. Mus. 2009, 5-6, 68-83.

56. Calcani, G. Museos y Sitios Arquelógicos en Italia. Seminario Centroamericano sobre la Conservación y la Valorización del Patrimonio Cultural, Guatemala, Antigua-El Salvador. San Salvador, El Salvador, 9-13 May 2011; Available online: https://joomla.iila.org/images / /Cooperazione/SEMINARIO/SESION_6.pdf (accessed on 11 December 2020).

57. UNESCO. Indicadores UNESCO de Cultura Para el Desarrollo. Manual Metodológico; UNESCO: París, France, 2014.

58. Forteza-Oliver, M. El papel de los museos en las Redes Sociales. Biblios 2012, 48, 32-40. [CrossRef]

59. Echazú, E. Glosario de Desarrollo Sostenible, Palabras Para Cambiar el Mundo. 2020. Available online: http://sedici.unlp.edu. ar/handle/10915/104701 (accessed on 16 November 2020).

60. Hootsuite \& We Are Social. Digital 2020: October Global Statshot; October 2020. Available online: https:/ / datareportal.com/ reports/digital-2020-october-global-statshot?rq=covid\%2019 (accessed on 16 November 2020).

61. Hootsuite \& We Are Social. Digital 2020: Italy; February 2020. Available online: https://datareportal.com/reports/digital-2020 -italy (accessed on 16 November 2020).

62. Ministerio de Cultura y Deporte. Encuesta de Hábitos y Prácticas Culturales 2018-2019; Statistics and Studies Division, General Technical Secretariat, Ministry of Culture and Sports: Madrid, Spain, 2019; Available online: https://www.culturaydeporte.gob. es/dam/jcr:1712f192-d59b-427d-bbe0-db0f3e9f716b/encuesta-de-habitos-y-practicas-culturales-2018-2019.pdf (accessed on 16 November 2020).

63. Pencarelli, T.; Conti, E.; Splendiani, S. The experiential offering system of museums: Evidence from italy. JCHMSD 2017, 7, 430-448. [CrossRef]

64. Hootsuite \& We Are Social. Digital 2020: April Global Statshot; April 2020. Available online: https://datareportal.com/reports/ digital-2020-april-global-statshot (accessed on 16 November 2020).

65. Asensio, M.; Asenjo, E. Lazos de luz azul. Museos y Tecnologías 1,2 y 3.0; Universitat Oberta de Catalunya, Editorial UOC: Barcelona, Spain, 2011.

66. Caerols-Mateo, R.; Viñarás-Abad, M.; Gonzálvez-Valles, J.E. Redes sociales y museos: Análisis de la campaña en Twitter para el Día Internacional de los Museos y Noche de los Museos. Rev. Lat. Comun. Soc. 2017, 72, 220-234.

67. Losada-Díaz, J.C.; Capriotti, P. La comunicación de los museos de arte en Facebook: Comparación entre las principales instituciones internacionales y españolas. Palabra Clave 2015, 18, 889-904. [CrossRef]

68. Museo Arqueológico Nacional. "Las Redes Sociales como Protagonistas Durante el Confinamiento". 2020. Available online: https:/ / www.youtube.com/watch?v=VQf_zFNOLqY\&t=140s (accessed on 17 November 2020).

69. Feldman, K. Leading the NATIONAL GALLERY of ART during COVID-19. Mus. Manag. Curatorship 2020. [CrossRef]

70. Blühm, A. The Groninger Museum experience. MMC 2020, 35, 225-226. [CrossRef]

71. Christiansen, K. The Met and the COVID crisis. MMC 2020, 35, 221-224. [CrossRef]

72. O'Reilly, T. What Is Web 2.0. Design Patterns and Business Models for the Next Generation of Software. 2005. Available online: http:/ / www.oreillynet.com/pub/a / oreilly/tim/news/2005/09/30/what-is-web-20.html (accessed on 16 November 2020). 
73. Cloutier, J. La Communication Audio-Scripto-Visuelle à l' Heure des Self Média; Les Presses de l'Université de Montréal: Montreal, QC, Canada, 1973.

74. Jenkins, H. Transmedia Storytelling. Moving Characters from Books to Films to Video Games can Make Them Stronger and More Compelling. 2003. Available online: https:/ / www.technologyreview.com/2003/01/15/234540/transmedia-storytelling/ (accessed on 16 November 2020).

75. Courtin, A.; Juanals, B.; Minel, J.L.; de Saint Léger, M. A tool-based methodology to analyze social network interactions in cultural fields: The use case "Museumweek". In Social Informatics 2014. Workshops, Lecture Notes in Computer Science; Aiello, L., McFarland, D., Eds.; Springer: Cham, Switzerland, 2015; Volume 8852, pp. 144-156.

76. Vassilakis, C.; Antoniou, A.; Lepouras, G.; Poulopoulos, V.; Wallace, M.; Bampatzia, S.; Bourlakos, I. Stimulation of reflection and discussion in museum visits through the use of social media. Soc. Netw. Anal. Min. 2017, 7, 40. [CrossRef]

77. Council of Europe. Council of Europe Framework Convention on the Value of Cultural Heritage for Society. Faro: Portugal, 2005. Available online: https://www.coe.int/en/web/conventions/full-list/-/conventions/rms/0900001680083746 (accessed on 16 November 2020).

78. Rivero, P.; García-Ceballos, S.; Aso, B.; Navarro-Neri, I. Augmented Reality in Spain: Heritage Education, Cultural Tourism and Museums. In Augmented Reality in Tourism, Museums and Heritage. A New Technology to Inform and Entertain; Geroimenko, V., Ed.; Springer Nature: Cham, Switzerland, in press.

79. Arvanitis, K. Museums outside Walls: Mobile phones and the museum in the everyday. In Heritage and Social Media: Understanding Heritage in a Participatory Culture; Giaccardi, E., Ed.; Routledge: London, UK, 2012.

80. Adell, J. Tendencias en educación en la sociedad de las tecnologías de la información. In Educar en la Sociedad de la Información; Area, M., Ed.; Editorial Desclée de Brouwer: Bilbao, Spain, 2001.

81. Deleuze, G.; Guattari, F. El anti Edipo. Capitalismo y esquizofrenia; Paidós: Barcelona, Spain, 1985; ISBN 2-7073-0067-5. 